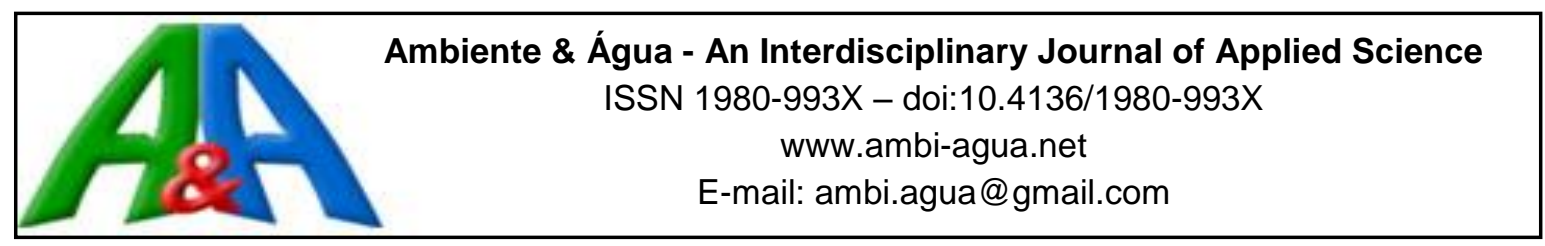

\title{
Optimization of nitrogen and phosphorus removal from pig slaughterhouse and packing plant wastewater through electrocoagulation in a batch reactor
}

\author{
ARTICLES doi:10.4136/ambi-agua.2233 \\ Received: 23 Jan. 2018; Accepted: 24 Jul. 2018

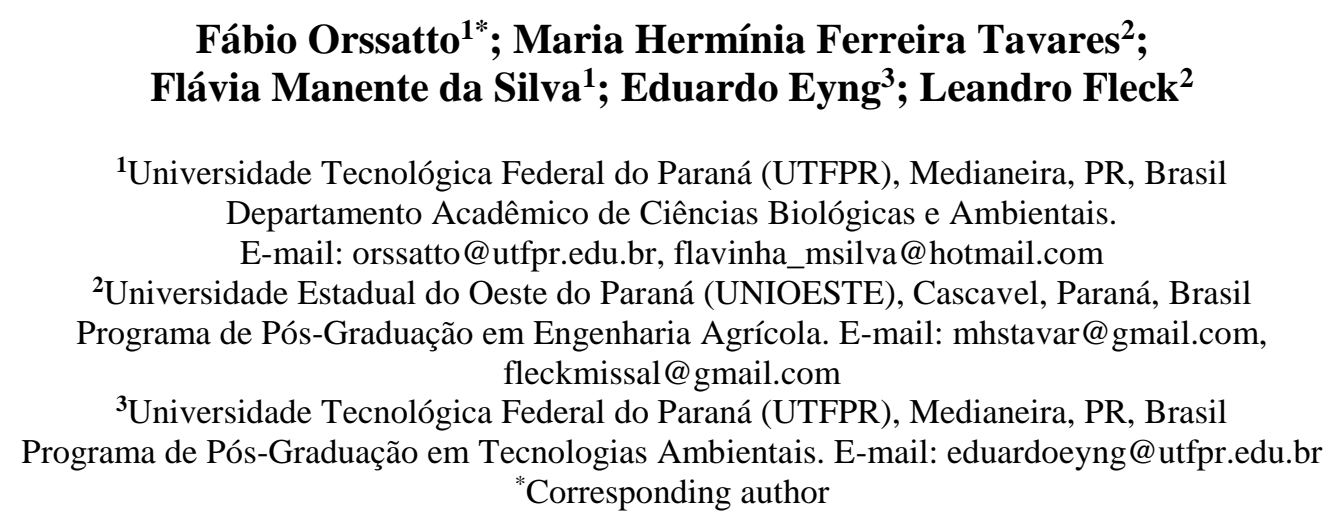

\section{ABSTRACT}

This work evaluated the removal of total Kjeldahl nitrogen (TKN) and total phosphorus (P) through electrocoagulation and used aluminum electrodes to optimize the potential differential (pd) and hydraulic retention time (HRT) variables in a batch reactor. The experimental design used was Rotatable Central Composite Design (RCCD). The application of the electrocoagulation in the treatment of effluents from pig slaughterhouses and packing plants proved to be efficient in relation to the removal of TKN and total phosphorus, obtaining maximum efficiency equal to $67.15 \%$ and $99 \%$, respectively. The maximum TKN removal value was found in Test 12, where treatment conditions were 30 minutes for HRT and 20 volts for pd, which corresponds to $0.86 \mathrm{~A}$ of electric current and a current density of $17.2 \mathrm{~mA} \mathrm{~cm} \mathrm{~cm}^{-2}$. For P, the only test that removed below $99 \%$ was the first. Through statistical analyses, it was only possible to obtain a mathematical model for TKN removal. While the response surface graph did not present a defined range of the best conditions for the independent variables, it was possible to observe the tendency for better removal, a wide range of $\mathrm{pd}$ and values over 30 minutes for retention time.

Keywords: electroflotation, electrolytic treatment, nutrients.

\section{Otimização da remoção de nitrogênio e fósforo de efluente de matadouro e frigorífico de suínos por meio da eletrocoagulação em reator batelada}

\section{RESUMO}

O objetivo desse trabalho foi avaliar a remoção de nitrogênio total kjeldahl (NTK) e fósforo total (P) através da eletrofloculação e otimizar as variáveis diferencial de potencial (ddp) e tempo de detenção hidráulica (TDH) em um reator batelada utilizando eletrodos de alumínio. 
O delineamento experimental utilizado foi o DCCR. A aplicação da técnica da eletrofloculação no tratamento de efluentes de matadouros e frigoríficos de suínos demonstrou ser eficiente no que tange a remoção de NTK e fósforo total obtendo-se eficiência máxima igual a $67,15 \%$ e $99 \%$, respectivamente. O valor máximo de remoção de NTK foi encontrado no ensaio 12, onde as condições de tratamento foram de 30 minutos para o TDH e 20 volts para a ddp o que corresponde a 0,86 A de corrente elétrica e uma densidade de corrente igual a 17,2 $\mathrm{mA} \mathrm{cm}$. Para o P, o único ensaio que removeu abaixo de $99 \%$ foi o primeiro. Através das análises estatísticas, foi possível obter modelo matemático apenas para a remoção de NTK, entretanto o gráfico da superfície de resposta não apresentou uma faixa definida das melhores condições para as variáveis independentes, mas foi possível observar a tendência para melhor remoção, uma ampla faixa de ddp e valores acima de 30 minutos para o tempo de detenção.

Palavras-chave: eletroflotação, nutrientes, tratamento eletrolítico.

\section{INTRODUCTION}

The production of pork in Brazil has great relevance for the country's economy. According to ABPA (2017), Brazil produced 3.73 million tons of pork in 2016, ranking 4th in the world.

Pig slaughterhouses and packing plants generate a large amount of effluents, which consist of protein, fat, salts, animal manure and other substances. This waste therefore has a high degree of pollution, with high levels of organic matter, oils and greases, nutrients and total solids.

In addition to the high degree of pollution, the meat processing industry produces large volumes of wastewater due to the slaughter of animals and the cleaning of slaughterhouses and meat processing plants (Bustillo-Lecompte and Mehrvar, 2015). The meat processing industry uses $24 \%$ of the total fresh water consumed by the food and beverage industry and up to $29 \%$ of the worldwide agricultural sector demand (Mekonnen and Hoekstra, 2012; Gerbens-Leenes et al, 2013).

In addition to the large amount of effluent generated, the wastewater from the slaughterhouses and packing plants contains several types of pollutants, among them nutrients.

Nutrients released into the water, especially nitrogen and phosphorus, contribute to the increase of primary productivity of the system, resulting in an accumulation of organic matter and reduction of light penetration (Azevedo et al., 2008).

Because of this, removing such nutrients from the wastewater is indispensable to minimize the impacts caused to the receiving bodies. Several techniques can be used to treat effluents generated in productive processes.

Jaafari et al. (2017) used Moving Bed Biofilm Reactors (MBBRs) for the simultaneous removal of organic matter and nutrients from wastewater. In this same context, Safari et al. (2015) and Naghipour et al. (2015) used the adsorption and biosorption processes for the removal of phosphorus in aqueous solutions.

Techniques involving electrochemical reactions have been studied in environmental applications, especially in the treatment of wastewater. One such process is electrocoagulation (EC) which has gained attention because of its attractive advantages such as simplicity and low operating cost (Deghles and Kurt, 2016).

EC involves the dissolution of a metal (usually iron or aluminum) in the anode with the simultaneous formation of hydroxyl ions, and the generation of hydrogen gas in the cathode, which can be recovered for use as an energy source or a reagent for other industrial applications (Phalakornkule et al., 2010).

According to Crespilho and Rezende (2004), EC occurs in four stages: electrochemical generation of the coagulating agent, electrocoagulation, electroflocculation and flotation of the impurities. 
The electrochemical generation of the coagulating agent occurs from the dissolution of the anode of aluminum electrodes subjected to an obtained electric current. In addition to the electric current, other factors should be considered, such as the conductivity of the solution, the resistivity of the medium and the potential applied between the electrodes (Crespilho and Rezende, 2004).

In electrocoagulation, the positively charged material can react with the negative charges of the solution. This causes the hydrolysis that releases aluminum hydroxide, responsible for the treatment of the effluent submitted to the process (Brito et al., 2012).

In the electroflocculation stage, the aluminum complexes are adsorbed in colloidal particles, giving rise to larger particles. This step consists of greater destabilization of the system and the flocs can be removed through flotation (Crespilho and Rezende, 2004).

Finally, electroflotation promotes the separation of the impurities by flotation. This occurs due to the applied potential-forming hydrogen microbubbles in the cathode. The formed hydrogen bubbles promote the entrainment of the formed flocs to the surface of the solution. An example of application using electrocoagulation with aluminum electrodes is the work of Esfandyari et al. (2015).

This work evaluated the removal of total Kjeldahl nitrogen (TKN) and total phosphorus (P) through electrocoagulation, and used aluminum electrodes to optimize the potential differential (pd) and hydraulic retention time (HRT) variables in a batch reactor.

\section{MATERIALS AND METHODS}

\subsection{Effluent from pig slaughterhouses and processing plants}

The effluent used in the study came from a pig slaughterhouse and a packing plant located in the western region of Paraná. This industry slaughters approximately 6,500 animals, producing a discharge of $5,200 \mathrm{~m}^{3}$ of effluent per day.

The treatment system of the studied plant is composed of preliminary treatment with sieves, decanters and grease traps, which aim to eliminate coarse solids, oils and greases from industrial activities.

In the sequence, the effluent is directed towards biological treatment, with a sequence of four lagoons, which carry out the removal of carbonaceous and nitrogenous organic matter, along with residual solids and pathogens. As a post-treatment, the effluent passes through a float, being then directed to the river.

The effluent used for the electrocoagulation tests was collected after the discharge of the decanters/grease traps, and was characterized by total Kjeldahl nitrogen $\left(4500-\mathrm{N}_{\text {org }} \mathrm{B}\right)$, total phosphorus (4500-PE), $\mathrm{pH}\left(4500-\mathrm{H}^{+} \mathrm{B}\right)$ and conductivity $(2510 \mathrm{~B})$, in accordance with APHA protocols (APHA et al., 2005).

\subsection{Batch experimental system}

The electrocoagulation treatment system consisted of a batch bench reactor composed of a 1-liter beaker containing $800 \mathrm{~mL}$ of effluent in each test. This system was maintained under constant stirring by means of a magnetic stirrer and a magnetic bar placed inside the beaker.

In order to provide the electric current that makes the electrocoagulation process viable, a direct current source, in which two metallic aluminum electrodes were connected and immersed in the effluent, was used. The electrodes were arranged at a distance of $7.8 \mathrm{~cm}$ and each plate was $10 \mathrm{~cm}$ long and $5 \mathrm{~cm}$ wide.

The best conditions for the treatment of the effluent were determined by testing different values for the variables: potential differential (pd) and hydraulic retention time (HRT). 


\subsection{Evaluation of the system}

To verify the best efficiency, the removal of Total Kjeldahl Nitrogen (TKN) and Total Phosphorus (P) was considered. The values of electric current (A) were also recorded so that it was possible to calculate the current density $\left(\mathrm{mA} \mathrm{cm}^{-2}\right)$.

\subsection{Experimental planning}

The design used was the Rotatable Central Composite Design (RCCD). As two independent variables (pd and HRT) were worked, a complete $2^{2}$ factorial was performed, including four axial points and four repetitions at the central point, totaling 12 tests.

Table 1 shows the number of tests with the coded and actual values, which were defined from pretests with the effluent. These pretests also showed that the addition of alkaline agents was not necessary and that the effluent had the necessary electrical conductivity for electrocoagulation to occur.

Table 1. Number of tests with coded values.

\begin{tabular}{ccc}
\hline Tests & pd $(\mathrm{V})$ & HRT $(\mathrm{min})$ \\
\hline 1 & $-1(12,91)$ & $-1\left(12^{\prime} 55^{\prime \prime}\right)$ \\
2 & $+1(27,09)$ & $-1\left(12^{\prime} 55^{\prime \prime}\right)$ \\
3 & $-1(12,91)$ & $1\left(27^{\prime} 05^{\prime \prime}\right)$ \\
4 & $+1(27,09)$ & $1\left(27^{\prime} 05^{\prime}\right)$ \\
5 & $0(20)$ & $0(20)$ \\
6 & $0(20)$ & $0(20)$ \\
7 & $0(20)$ & $0(20)$ \\
8 & $0(20)$ & $0(20)$ \\
9 & $-1,41(10)$ & $0(20)$ \\
10 & $+1,41(30)$ & $0(20)$ \\
11 & $0(20)$ & $-1,41(10)$ \\
12 & $0(20)$ & $+1,41(30)$ \\
\hline
\end{tabular}

From the results, it was possible to calculate the effects of the variables, the respective errors and the analysis of variance (ANOVA) to verify the quality of adjustment of the obtained model, which related the response variable to the other independent variables tested, as well as the effect among these. The graphical representation of this model consisted of a surface chart, which aided in the determination of the optimum operating region of the system.

The regression analysis of the data obtained through the RCCD allowed for the adjustment of the parameters of quadratic models of the response variables, as a function of the studied factors and their interactions. Equation 1 represents a general model to be obtained, and the $\alpha$ parameters were adjusted by regression analysis.

Removal of TKN or $P=\alpha_{1}+\alpha_{2} p d+\alpha_{3} H R T+\alpha_{4} p d . H R T+\alpha_{5} p d^{2}+\alpha_{6} H R T^{2}$

Where HRT is time in minutes and pd is the potential differential in volts.

\section{RESULTS AND DISCUSSION}

\subsection{Characterization of the crude effluent}

Regarding the characterization of the crude effluent, the following values were found: $289.8 \mathrm{mgN} \mathrm{L}^{-1}$ for the total Kjeldahl nitrogen parameter, $38 \mathrm{mgP} \mathrm{L}^{-1}$ for phosphorus, $3.91 \mathrm{mS} \mathrm{cm}^{-1}$ for conductivity and a $\mathrm{pH}$ equal to 6.46 .

In analyzing the values, it was observed that the majority of the parameters had high 
indexes, with the exception of $\mathrm{pH}$. Corroborating with the found values, Bustillo-Lecompte et al. (2014) report that wastewater from packing plants may have total nitrogen concentrations ranging from 50 to $841 \mathrm{mg} \mathrm{L}^{-1}$ and a $\mathrm{pH}$ range of 4.90 to 8.10 .

Pan et al. (2014) found, on average, $172.6 \mathrm{mg} \mathrm{L}^{-1}$ of total nitrogen and $52 \mathrm{mg} \mathrm{L}^{-1}$ total phosphorus, when characterizing packing plant effluent.

Palatsi et al. (2011), in their work on the biodigestion of packing plant waste, characterized the effluent and found on average $150 \mathrm{mg} \mathrm{L}^{-1}$ of total Kjeldahl nitrogen.

\subsection{Efficiency of removal}

Figure 1 shows the removal efficiency values for TKN and Total Phosphorus parameters in the 12 tests performed.

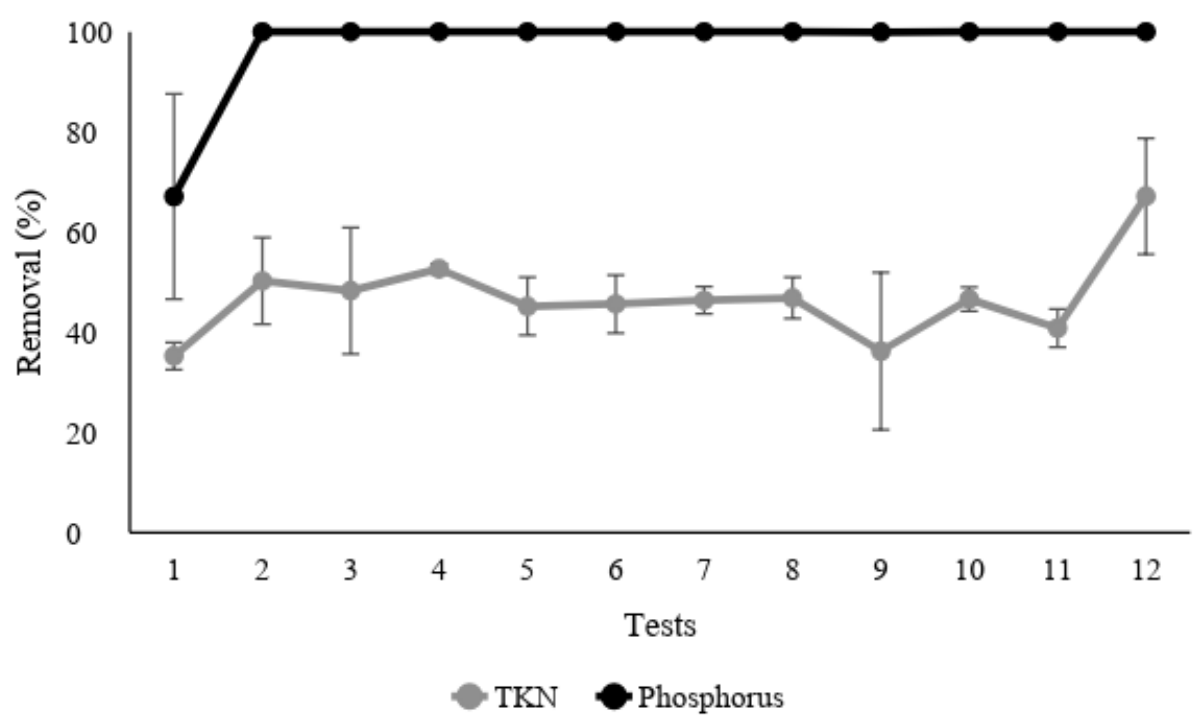

Figure 1. Efficiency of removal of TKN and total phosphorus parameters.

Different behaviors for the removal of TKN and phosphorus can be observed in the graph in Figure 1, such as a high efficiency for phosphorus and satisfactory removal of TKN.

For phosphorus, the lowest removal occurred in Test $1,67.10 \%( \pm 20,47)$, and the other tests showed efficiency above 99\%. Nunes (2012) points out that the use of chemical precipitation is common for the removal of phosphorus and, for this to occur, aluminum sulfate or the combination of ferric chloride with lime is used. With the use of aluminum sulfate, a $95 \%$ removal of phosphorus can be obtained, a result similar to the one previously found, as the electrodes used were aluminum.

According to Nunes (2012), the phosphorus is removed as phosphate $\left(\mathrm{PO}_{4}{ }^{3-}\right)$ and the chemical reaction outlined in Equation 2 occurs.

$\mathrm{Al}^{3+}+\mathrm{PO}_{4}^{3-} \rightarrow \mathrm{AlPO}_{4}$

Gökkus and Yildiz (2015) applied electrocoagulation in the treatment of wastewater from hospital waste-sterilization plants; they removed $100 \%$ of the phosphorus present in the effluent.

While studying phosphorus removal and turbidity of pork effluent with aluminum electrodes, HRT of $80 \mathrm{~min}$ and current density of $50 \mathrm{~mA} \mathrm{~cm}{ }^{-2}$, Mores et al (2016) obtained a removal of $93.6 \%$ of total phosphorus.

Khennoussi et al. (2013), when treating wastewater from a slaughterhouse and packing plant with electrocoagulation, applying a voltage of $12 \mathrm{~V}, 25 \mathrm{~min}$ contact time and iron electrodes, obtained a removal of $95.4 \%$ orthophosphate.

\section{IPABH}

Rev. Ambient. Água vol. 13 n. 5, e2233 - Taubaté 2018 
For TKN, the removal efficiency values ranged from $35.26 \%( \pm 2.73)$ to $67.15 \%( \pm 11.61)$. Test 12 showed the best removal efficiency with 30 minutes of hydraulic retention time and 20 volts of potential differential, corresponding to $0.86 \mathrm{~A}$ of electrical current, and current density of $17.2 \mathrm{~mA} \mathrm{~cm}^{-2}$; however, excluding the least efficient test, the variation compared to the other assays was low, having a standard deviation of 7.76 .

Kabuk et al. (2014) applied electrocoagulation in the Leachate treatment and obtained a removal efficiency of TKN removal efficiency of $32 \%$.

Khennoussi et al. (2013), in the same paper cited above, obtained a removal of $76.2 \%$ of total nitrogen.

The biological removal of the nitrogen present in liquid effluents is possible through a series of reactors, where the processes of nitrification and denitrification occur. These methods are efficient; however, they require more time and space since the removal of organic matter must occur first and then the specific removal of nitrogen.

In addition, the process of nitrification and denitrification also demands electric power since it is necessary to supply oxygen to the nitrifying bacteria to convert the ammoniacal nitrogen into nitrite and nitrate, and for homogenization of the denitrification tank.

$\mathrm{Hu}$ et al. (2013) state that for both nitrification and denitrification processes, large energy consumption is required, resulting in relatively high costs for treatment systems.

In this manner, a high removal of nutrients in the electrocoagulation process was observed, using a significantly shorter time than in traditional biological processes.

\subsection{Optimization of the electrocoagulation process}

Through the results, it was possible to evaluate a mathematical model for the removal of TKN and total phosphorus.

Parameters with p-values less than 5\% were considered significant, as can be observed in Figures 2, 3 and in Table 2, which represent the pareto charts for the removal of the parameters studied; the linear terms are associated with the letter $\mathrm{L}$ and the quadratic terms with the letter Q.

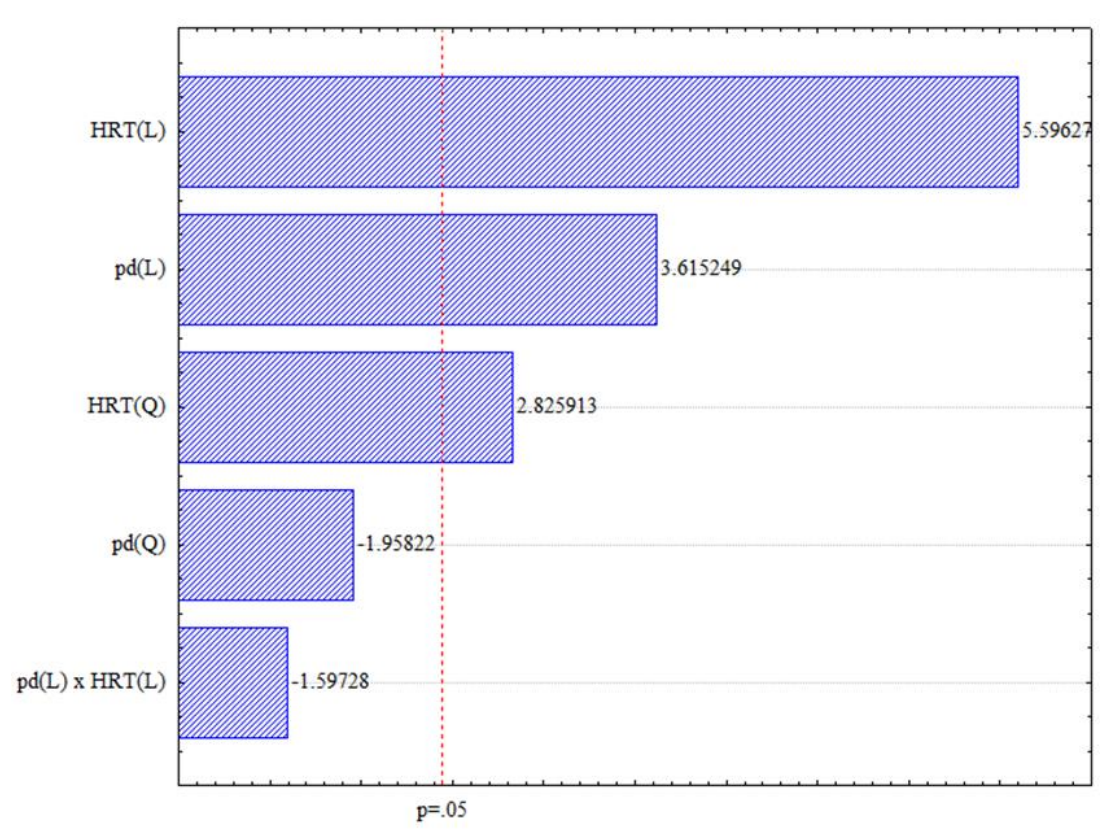

Figure 2. Pareto chart for the removal of TKN. 


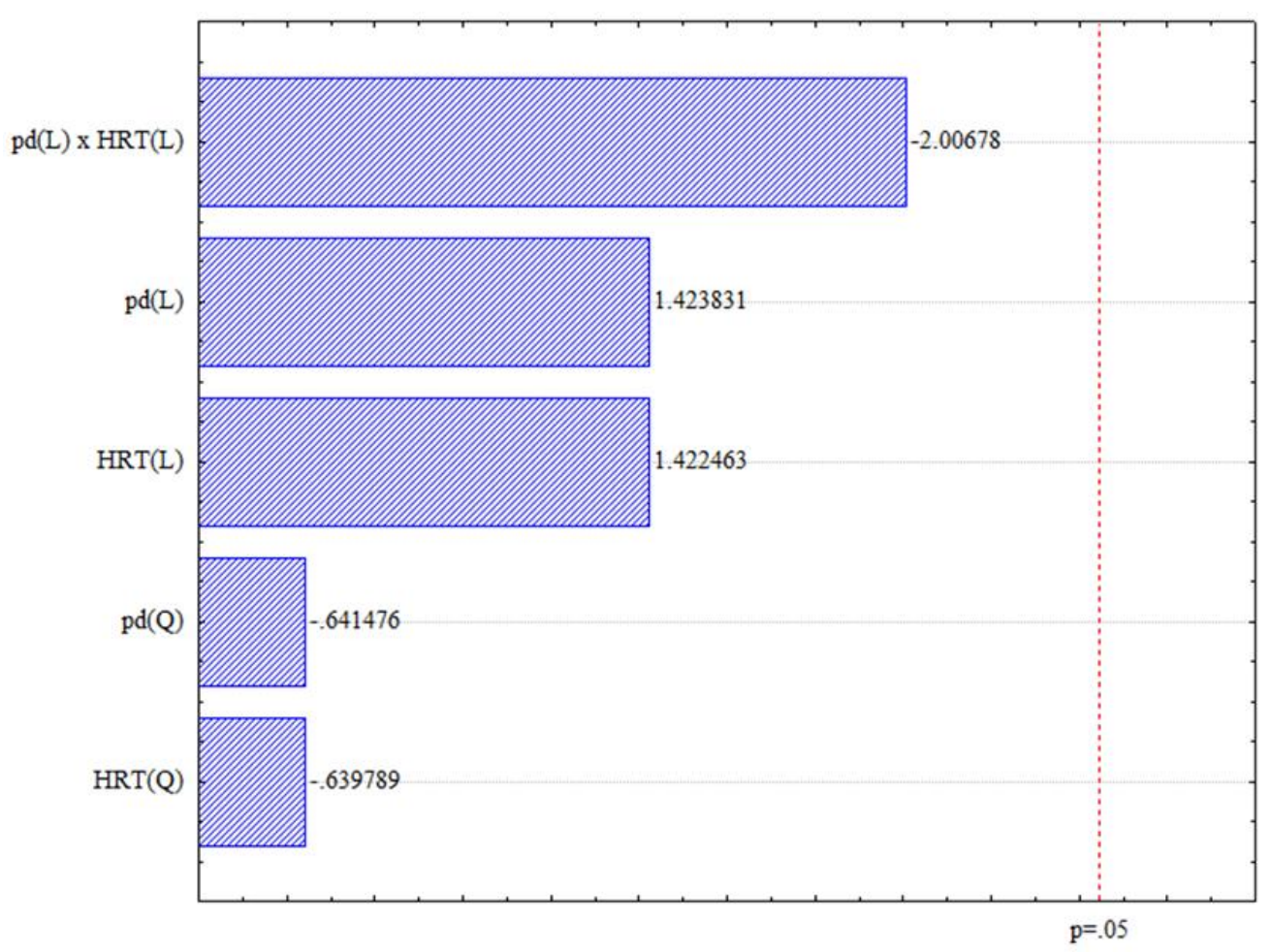

Figure 3. Pareto chart for the removal of total phosphorus.

Table 2. Regression coefficients for the response variable NTK removal.

\begin{tabular}{|c|c|c|c|c|c|c|}
\hline \multirow[b]{2}{*}{ Factors } & \multirow[b]{2}{*}{$\begin{array}{l}\text { Regression } \\
\text { coeficiente }\end{array}$} & \multirow[b]{2}{*}{$\begin{array}{l}\text { Standard } \\
\text { error }\end{array}$} & \multirow[b]{2}{*}{$\mathrm{t}(6)$} & \multirow[b]{2}{*}{$\mathrm{p}$ - value } & \multicolumn{2}{|c|}{ Estimates per interval (95\%) } \\
\hline & & & & & Lower limit & Upper limit \\
\hline Average & 46.01776 & 1.663442 & 27.66419 & 0,000000 & 41.9475 & 50.08805 \\
\hline $\mathrm{pd}(\mathrm{L})$ & 4.25874 & 2.355990 & 3.61525 & 0,011161 & 2.7526 & 14.28239 \\
\hline $\mathrm{pd}(\mathrm{Q})$ & -2.58596 & 2.641143 & -1.95822 & 0,097937 & -11.6346 & 1.29072 \\
\hline HRT (L) & 6.59238 & 2.355990 & 5.59627 & 0,001386 & 7.4199 & 18.94966 \\
\hline $\operatorname{HRT}(\mathrm{Q})$ & 3.73182 & 2.641143 & 2.82591 & 0,030119 & 1.0010 & 13.92629 \\
\hline pd HRT & -2.65700 & 3.326913 & -1.59728 & 0,161317 & -13.4547 & 2.82665 \\
\hline
\end{tabular}

In Figure 2 and Table 2, it can be observed that for the TKN removal variable response the significant terms were pd (L), HRT (L) and HRT (Q).

However, for the total-phosphorus removal response variable (Figure 3), no term was significant, which was already expected when observing the behavior of the values in the chart of Figure 1, as similar removals were obtained for the majority of the assays. Thus, it was only possible to obtain a mathematical model for the TKN removal response variable.

It can be observed that the adjusted model for the TKN response variable was characterized by Equation 3.

Removal of $T K=46.01776+4.25874 p d+6.59238 H R T+3.73182 H R T^{2}$

The analysis of variance (ANOVA) of the results found for the removal of TKN showed that the obtained model fits the data, since the p-value was 0.004685 , with a variation percentage of explained variation $\left(\mathrm{R}^{2}\right)$ of $91.12 \%$ evidencing a valid model. Figure 4 shows the response surfaces for the removal of TKN. 


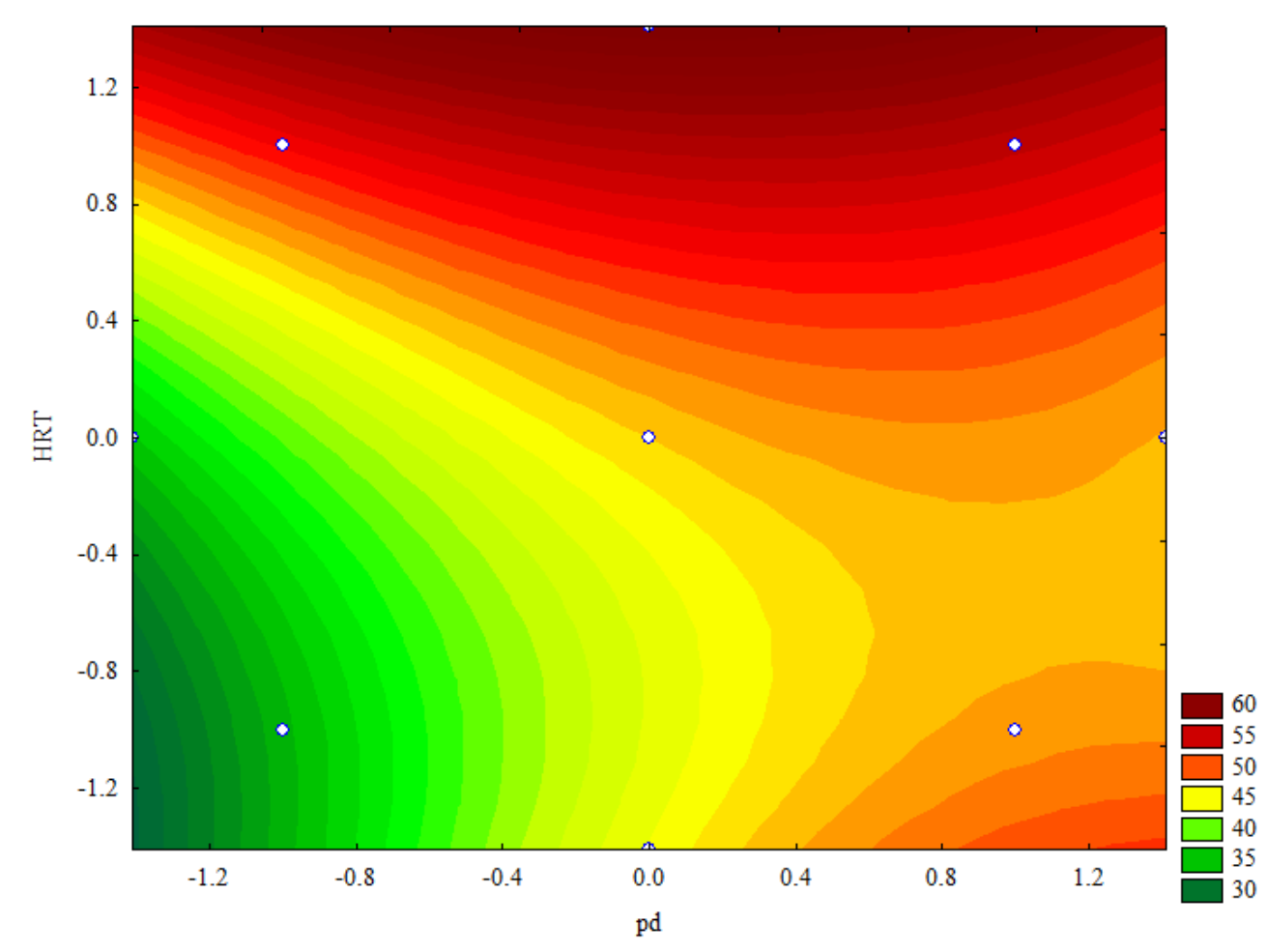

Figure 4. Response surface for removal of TKN.

For TKN removal, the response surface did not present an approximate range for the best removal conditions; however, it is possible to observe a tendency for a better removal, a wide range of pd and values over 30 minutes for retention time.

\section{CONCLUSION}

The objective of this work was to evaluate the removal of total Kjeldahl nitrogen (TKN) and total phosphorus (P) through the electrochemical technique, and to optimize the potential differential (pd) and hydraulic retention time (HRT) variables in a batch reactor of electrocoagulation using aluminum electrodes.

The application of electrocoagulation in the treatment of effluents from pig slaughterhouses and packing plants proved to be efficient in relation to the removal of TKN and total phosphorus, obtaining maximum efficiency equal to $67.15 \%$ for TKN and $99 \%$ for total phosphorus.

The maximum TKN removal value was found in test 12 , where treatment conditions were 30 minutes for HRT and 20 volts for pd, which corresponds to $0.86 \mathrm{~A}$ of electric current and a current density equal to $17.2 \mathrm{~mA} \mathrm{~cm}^{-2}$.

For total phosphorus, the only assay that removed below $99 \%$ was the first, showing that, for phosphorus removal, electrocoagulation is an excellent treatment option.

Through statistical analyses, it was only possible to obtain a mathematical model for the removal of TKN. However, the response surface chart did not present a defined range of the best conditions for the independent variables, but it was possible to observe the tendency for better removal across a wide range of $\mathrm{pd}$ and values above 30 minutes for retention time.

As suggestions for future work, $\mathrm{pH}$ can be evaluated as a variable, even if this implies a change in the initial characteristics of the effluent, in an attempt to increase the efficiency of nitrogen removal. Higher levels of electrolysis time can also be tested since the response surface graph showed a trend of increased efficiency with higher HRT. 


\section{REFERENCES}

AMERICAN PUBLIC HEALTH ASSOCIATION - APHA; AMERICAN WATER WORKS ASSOCIATION - AWWA; WATER ENVIRONMENT FEDERATION - WEF, Standard methods for the examination of water and wastewater. 22. ed. Washington, DC, 2005.ASSOCIAÇÃO BRASILEIRA DE PROTEÍNA ANIMAL - ABPA. Relatório anual. 2017. Disponível em: https://goo.gl/unpxGV Acesso em: jul. 2018.

AZEVEDO, A.C. G de; FEITOSA, F. A. N.; KOENING, M. L. Distribuição espacial e temporal da biomassa fitoplanctônica e variáveis ambientais no Golfão Maranhense, Brasil. Acta Botânica Brasilica, v. 22, n. $\quad 3, \quad 2008$. https://doi.org/10.1590/S010233062008000300022

BRITO, J. F.; FERREIRA, L. O.; SILVA, J. P. Tratamento da água de purificação do biodiesel utilizando eletrofloculação. Química Nova, v. 35, n. 4, 2012. http://dx.doi.org/10.1590/S0100-40422012000400014

BUSTILLO-LECOMPTE, C. F.; MEHRVAR, M. Slaughterhouse wastewater characteristics, treatment, and management in the meat processing industry: A review on trends and advances. Journal of Environmental Management. v. 161, n. 287, 2015. http://dx.doi.org/10.1016/j.jenvman.2015.07.008

BUSTILLO-LECOMPTE, C. F.; MEHRVAR, M.; QUIÑONES-BOLAÑOS, E. Costeffectiveness analysis of TOC removal from slaughterhouse wastewater using combined anaerobic-aerobic and UV/ $\mathrm{H}_{2} \mathrm{O}_{2}$ processes. Journal of Environmental Management. v. 134, 2014. http://dx.doi.org/10.1016/j.jenvman.2013.12.035

CRESPILHO, F. N.; REZENDE, M. O. O. Teoria da eletroflotação. In: CRESPILHO, F. N.; REZENDE, M. O. O. Eletroflotação: Princípios e aplicações. São Carlos: Rima, 2004. p.1-12.

DEGHLES, A.; KURT, U. Treatment of tannery wastewater by a hybrid electrocoagulation/ electrodialysis process. Chemical Engineering and Processing: Process Intensification. v. 104, 2016. http://dx.doi.org.10.1016/j.cep.2016.02.009

ESFANDYARI, Y.; MAHDAVI, Y.; SEYEDSALEHI, M.; HOSEINI, M.; SAFARI, G. H.; GHOZIKALI, M. G. et al. Degradation and biodegradability improvement of the olive mill wastewater by peroxi- electrocoagulation/electrooxidation-electroflotation process with bipolar aluminum electrodes. Environmental Science Pollution Research. v. 22, n. 8, p. 6288-6297, 2015. https://doi.org/10.1007/s11356-014-3832-5

GERBENS-LEENES, P. W.; MEKONNEN, M. M.; HOEKSTRA, A. Y. The water footprint of poultry, pork and beef: a comparative study in different countries and production $\begin{array}{llllll}\text { systems. Water Resources and Industry, v. } 2013 . & \end{array}$ http://dx.doi.org/10.1016/j.wri.2013.03.001

GÖKKUS, Ö.; YILDIZ, Y. S. Application of electrocoagulation for treatment of medical waste sterilization plant wastewater and optimization of the experimental conditions. Clean $\begin{array}{lllllll}\text { Technologies Environmental Policy. } & \text { v. 17, n. 6, } 2015 .\end{array}$ http://dx;doi.org/10.1007/s10098-014-0897-2

HU, Z.; LOTTI, T.; KREUK, M.; KLEERBEZEM, R.; VAN LOOSDRECHT, M; KRUIT, J. et al. Nitrogen removal by a nitritation-anammox bioreactor at low temperature. Applied and Environmental Microbiology, v. 79, n. 8, p. 2807-2812, 2013. http://dx.doi.org/10.1128/AEM.03987-12 
JAAFARI, J.; SEYEDSALEHI, M.; SAFARI, G. H.; ARJESTAN, M. E.; BARZANOUMI, H.; GHADIMI, S. et al. Simultaneous biological organic matter and nutrient removal in an anaerobic/anoxic/oxic (A2O) moving bed biofilm reactor (MBBR) integrated system. International Journal Environmental Science and Technology, v. 14, p. 291-304, 2017. https://doi.org/10.1007/s13762-016-1206-x

KHENNOUSSI, A.; CHAOUCH, M.; CHAHLAOUI, A. Traitement des effluents d'abattoir de viande rouge par électrocoagulation-flottation avec des électrodes en fer. Erudit. v. 26, n. 2, p. 135-150, 2013. http://dx.doi.org/10.7202/1016064ar

KABUK, H. A.; IILHAN, F.; AVSAR, Y.; KURT, U.; APAYDIN, O.; GONULLU, M. T. Investigation of Leachate Treatment with Electrocoagulation and Optimization by Response Surface Methodology. Clean Soil Air Water, v. 42, n. 5, p.571-577, 2014. https://doi.org/10.1002/clen.201300086

MEKONNEN, M.M.; HOEKSTRA, A.Y. A global assessment of the water footprint of farm animal products. Ecosystems. v. 15, n.3, 2012. http://dx.doi.org/10.1007/s 10021-0119517-8

MORES, R.; TREICHEL, H.; ZAKRZEVSKI, C. A.; KUNZ, A.; STEFFENS, J.; DALLAGO, R. M. Remove of phosphorous and turbidity of swine wastewater using electrocoagulation under continuous flow. Separation and Purification Technology. v. 171, 2016. https://doi.org/10.1016/j.seppur.2016.07.016

NAGHIPOUR, D.; TAGHAVI, K.; JAAFARI, J.; MAHDAVI, Y.; GHOZIKALI, M. J.; AMERI, R. et al. Statistical modeling and optimization of the phosphorus biosorption by modified Lemna minor from aqueous solution using response surface methodology (RSM). Desalination and Water Treatment, v. 57, n. 41, p. 19431-19442, 2015. https://doi.org/10.1080/19443994.2015.1100555

NUNES, J. A. Processos químicos específicos e tratamentos terciários. In: NUNES, J. A. Tratamento Físico-Químico de Águas Residuárias Industriais. Aracaju: J. Andrade, 2012. p. 175-208.

PALATSI, J.; VIÑAS, M.; GUIVERNAU, M.; FERNANDEZ, B.; FLOTATS, X. Anaerobic digestion of slaughterhouse waste: Main process limitations and microbial community interactions. Bioresource Technology. $\quad$ v. 102, $\quad$ n. $3,2011$. http://dx.doi.org/10.1016/j.biortech.2010.09.121

PAN, M; WEN, X.; WU, G.; ZHANG, M.; ZHAN, X. Characteristics of nitrous oxide $\left(\mathrm{N}_{2} \mathrm{O}\right)$ emission from intermittently aerated sequencing batch reactors (IASBRs) treating slaughterhouse wastewater at low temperature. Biochemical Engineering Journal. v. 86, 2014. http://dx.doi.org/10.1016/j.bej.2014.03.003

PHALAKORNKULE, C.; SUKKASEM, P.; MUTCHIMSATTHA, C. Hydrogen recovery from the electrocoagulation treatment of dye-containing wastewater. International $\begin{array}{llllllll}\text { Journal Of Hydrogen Energy. } & \text { v. } & 35, & \text { n. } & 2010 .\end{array}$ http://dx.doi.org/10.1016/j.ijhydene.2010.06.100

SAFARI, J. H.; ZARRABI, M.; HOSEINI, M.; KAMANI, H.; JAAFARI, J.; MAHVI, A. H. Trends of natural and acid-engineered pumice onto phosphorus ions in aquatic environment: adsorbent preparation, characterization, and kinetic and equilibrium modeling. Desalination and Water Treatment, v. 54, n. 11, p. 3031-3043. 2015. https://doi.org/10.1080/19443994.2014.915385 